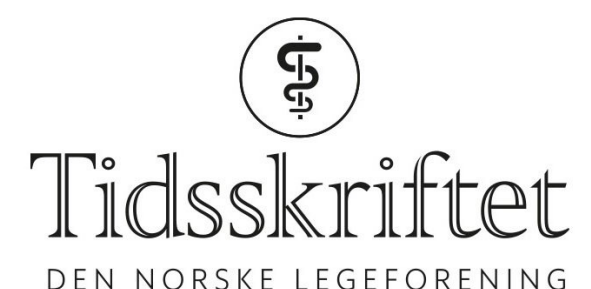

DEN NORSKE LEGEFORENING

\title{
Tran inneholder også miljøgifter
}

DEBATT

\section{ANNE-LISE BJØRKE-MONSEN}

E-post:almo@helse-bergen.no

Anne-Lise Bjørke-Monsen er førsteamanuensis ved Universitetet i Bergen, overlege ved Laboratorium for klinisk biokjemi, Haukeland universitetssykehus, og spesialist i barnesykdommer og medisinsk biokjemi.

Forfatter har fylt ut ICMJE-skjemaet og oppgir ingen interessekonflikter.

\section{SANDRA HUBER}

Sandra Huber er spesialrådgiver ved Laboratoriemedisin, Universitetssykehuset Nord-Norge. Forfatter har fylt ut ICMJE-skjemaet og oppgir ingen interessekonflikter.

\section{MARIA AVERINA}

Maria Averina er spesialist i medisinsk biokjemi, overlege ved Laboratoriemedisin, Universitetssykehuset Nord-Norge, og forsker ved UiT Norges arktiske universitet. Forfatter har fylt ut ICMJE-skjemaet og oppgir ingen interessekonflikter.

\section{JAN BROX}

Jan Brox er avdelingsoverlege ved Laboratoriemedisin, Universitetssykehuset Nord-Norge og spesialist i medisinsk biokjemi.

Forfatter har fylt ut ICMJE-skjemaet og oppgir ingen interessekonflikter.

\section{BJ ØRN J. BOLANN}

Bjørn J. Bolann er spesialist i indremedisin og medisinsk biokjemi, professor emeritus ved Universitetet i Bergen.

Forfatter har fylt ut ICMJE-skjemaet og oppgir ingen interessekonflikter.

Tran inneholder miljøgifter i varierende grad. Ettersom anbefalt mengde tran er lik for alle over 1 år, vil innholdet av miljøgifter ha størst betydning for de med lavest kroppsvekt, nemlig småbarn.

Tradisjonelt har norske helsemyndigheter anbefalt daglig inntak av tran til alle aldersgrupper. Fra 2001 ble anbefalt mengde tran til spedbarn halvert fra $5 \mathrm{~mL}$ til 2,5 $\mathrm{mL}(1)$ og fra september 2020 er det ikke lenger anbefalt å gi tran til spedbarn $(2,3)$. Disse endringene skyldes at tran gir for lite vitamin D og for mye av omega-3 fettsyren dokosaheksaensyre (DHA), som man frykter kan gi helseskade.

Eldre barn og voksne anbefales imidlertid fortsatt å ta tran, men mengden synes å være uavklart. I gamle dager var rådet å ta en barneskje (10 mL) eller spiseskje $(15 \mathrm{~mL})$ tran daglig, men den anbefalte mengden tran synes nå å være regulert av behovet for vitamin D. For barn og voksne er anbefalt daglig inntak av vitamin D $10 \mu \mathrm{g} / \mathrm{dag}$, mens eldre anbefales 20 $\mu \mathrm{g} /$ dag. En teskje tran vil gi $10 \mu \mathrm{g}$ vitamin D, mens en spiseskje gir $24 \mu \mathrm{g}$ vitamin D (4). 
Tran er fiskeolje og inneholder en rekke miljøgifter, noe som både i tidligere og nye råd fra helsemyndighetene er omtalt i liten grad

Tran er fiskeolje og inneholder en rekke miljøgifter $(5,6)$, noe som både i tidligere og nye råd fra helsemyndighetene er omtalt i liten grad. Miljøgifter gir helseskade, og inntaket av miljøgifter som dioksiner og dioksin-lignende polyklorerte difenyler (dl-PCB) i ulike populasjoner er derfor av interesse.

Mengden helseskadelige miljøgifter måles i pikogram (pg) toksiske ekvivalenter (TE) per kg kroppsvekt per uke. Den gamle tålegrensen for dioksiner og dl-PCB var $14 \mathrm{pg} \mathrm{TE} / \mathrm{kg}$ kroppsvekt per uke. I 2018 reduserte Den europeiske myndighet for næringsmiddeltrygghet (EFSA) denne grensen til 2 pg TE/kg kroppsvekt per uke (7). Bakgrunnen for denne endringen var tre studier som alle påviste en sammenheng mellom nivået av dioksiner hos gutter i barnealder og redusert sædkvalitet i voksen alder (8-10).

En undersøkelse basert på 68 populasjoner i Europa, hvor Norge ikke er representert, viste at det er småbarn som har den høyeste eksponeringen av dioksiner og dl-PCB (11). Denne studien ble publisert i 2012, og nivået av denne gruppen miljøgifter har siden blitt redusert (7).

Folkehelseinstituttet angir på sine sider at anbefalt inntak av en barneskje tran daglig vil i ubetydelig grad øke inntaket av dioksiner og dl-PCB ( $<3 \%$ av det totale inntaket), fordi tran renses for dette $(12,13)$. Imidlertid inneholder tran og omega-3-produkter fortsatt dioksiner og dl-PCB i varierende grad, og ettersom anbefalt mengde tran er felles for alle over ett år, så vil dette ha størst betydning for de med lavest kroppsvekt, nemlig småbarn.

Ettersom disse miljøgiftene i likhet med mange andre har klare negative helseeffekter, må eksponeringen, spesielt til barn og unge, minimaliseres

Mattilsynet har publisert undersøkelser av miljøgifter i ulike oljer for humant konsum (5, 6). Nivået av dioksiner og dl-PCB varierte opptil 2,o pg TE/g, hvorav Møllers «Min første tran» hadde det laveste nivået. Denne er anbefalt for barn opp til 3 år og inneholder o,26 pg/TE/g sum dioksiner og dl-PCB (5). Tabell 1 viser inntak av dioksiner og dl-PCB per uke fra en teskje ( $5 \mathrm{~mL}, 4,5$ gram) daglig av ulike trantyper. For en barneskje blir mengden det dobbelte av det tabellen viser.

\section{Tabell 1}

Dioksiner og dl-PCB ved inntak av tran hos et ett år gammelt barn $(5,6)$.

\begin{tabular}{|c|c|c|c|c|c|c|}
\hline \begin{tabular}{|l} 
Innhold i \\
tran på \\
norsk \\
marked
\end{tabular} & $\begin{array}{r}\text { Innhold } \\
\text { per gram } \\
\text { fett }\end{array}$ & $\begin{array}{r}\text { teskje } \\
(4,5 \mathrm{~g}) \\
\text { inneholder }\end{array}$ & $\begin{array}{r}\text { teskje } \\
\text { daglig } \\
\text { utgjør } \\
\text { per uke }\end{array}$ & $\begin{array}{r}\text { Tålegrense } \\
\text { per kg } \\
\text { kroppsvekt }\end{array}$ & $\begin{array}{r}\text { Tålegrense } \\
\text { for barn } \\
\text { på } 1 \text { år } \\
(9,5 \mathrm{~kg})\end{array}$ & $\begin{array}{r}\text { Inntak som } \\
\text { andel av } \\
\text { tålegrensen } \\
(\%)\end{array}$ \\
\hline Lavest $^{1}$ & 0,26 & 1,17 & 8,19 & 2 & 19 & 43 \\
\hline Middels & 0,47 & 2,12 & 14,81 & 2 & 19 & 78 \\
\hline Høyest & 2,0 & 9,0 & 63,0 & 2 & 19 & 332 \\
\hline
\end{tabular}

${ }^{1}$ Anbefalt for barn opptil 3 år

For alle småbarn vil tran altså utgjøre et betydelig bidrag av dioksiner og dl-PCB. Dette kommer i tillegg til bidrag fra andre kilder. Melk og melkeprodukter er angitt å være hovedkilden til miljøgifter i denne aldersgruppen, dersom barnet ikke spiser mye fisk og sjømat (11).

Dioksiner og dl-PCB er miljøgifter med lang halveringstid i mennesket og overføres til barnet under svangerskap og amming (14). Ettersom disse miljøgiftene i likhet med mange andre har klare negative helseeffekter, må eksponeringen, spesielt til barn og unge, 
minimaliseres.

Noen barn har behov for tilskudd av vitamin D og andre mikronæringsstoffer. Det er i dag mulig å få dette uten samtidig å få påfyll av miljøgifter. Rådgivning om tilskudd til ulike aldersgrupper bør ta hensyn til dette.

\section{LITTERATUR:}

1. Anbefalinger for spedbarnsernæring. Rapport IS-2170.Oslo: Statens råd for ernæring og fysisk aktivitet, 2001.

https://www.helsedirektoratet.no/rapporter/anbefalinger-om-kosthold-ernaering-og-fysisk-aktivitet/A nbefalinger\%2oom\%2okosthold\%2oern\%C3\%A6ring\%2oog\%2ofysisk\%2oaktivitet.pdf/_/attachment/inli ne/2f5d8ob2-eof7-4071-

a2e5-3bo8of99d37d:2aed64b5b986acd14764b3aa7fba3f3c48547d2d/Anbefalinger\%20om\%2okosthold\%20 ern\%C3\%A6ring\%20og\%2ofysisk\%2oaktivitet.pdf Lest 3.2.2021.

2. Hay G, Fadnes L, Holven KB et al. Nye råd om D-vitamintilskudd og tran til spedbarn. Tidsskr Nor Legeforen 2020; 140: 1628-30.

3. Helsedirektoratet. Nye råd om D-vitamintilskudd og tran til spedbarn. https://www.helsedirektoratet.no/nyheter/nye-rad-om-d-vitamintilskudd-og-tran-til-spedbarn Lest 9.10.2020.

4. Brustad M, Meyer H. Vitamin D - hvor mye er nok, og er mer bedre for helsen? Tidsskr Nor Legeforen 2014; 134: 725-8. [CrossRef]

5. Nilsen BM, Sanden M. Miljøgifter i fisk og fiskevarer 2018, Organiske miljøgifter, tungmetaller, 3MCPD og glysidylestere i marine oljer til humant konsum. Rapport fra Havforskningen 2019-33. Oslo: Havforskningsinstituttet, 2019. https://imr.brage.unit.no/imr-xmlui/handle/11250/2640686 Lest 9.10.2020.

6. Nilsen B, Wiechn M, Sanden M. Miljøgifter i fisk og fiskevarer 2019-Organiske miljøgifter, tungmetaller, 3-MCPD og glysidylestere i marine oljer til humant konsum. Rapport fra Havforskningen 2020-25. Oslo: Havforskningsinstituttet, 2020.

7. Knutsen HK, Alexander J, Barregård L et al. Risk for animal and human health related to the presence of dioxins and dioxin-like PCBs in feed and food. EFSA J 2018; 16: e05333. [PubMed]

8. Mocarelli P, Gerthoux PM, Patterson DG et al. Dioxin exposure, from infancy through puberty, produces endocrine disruption and affects human semen quality. Environ Health Perspect 2008; 116: 70-7. [PubMed][CrossRef]

9. Mocarelli P, Gerthoux PM, Needham LL et al. Perinatal exposure to low doses of dioxin can permanently impair human semen quality. Environ Health Perspect 2011; 119: 713-8.

[PubMed][CrossRef]

10. Mínguez-Alarcón L, Sergeyev O, Burns JS et al. A longitudinal study of peripubertal serum organochlorine concentrations and semen parameters in young men: The Russian Children's Study. Environ Health Perspect 2017; 125: 46o-6. [PubMed][CrossRef]

11. European Food Safety Authority. Update of the monitoring of levels of dioxins and PCBs in food and feed. EFSA J 2012; 10: 2832 .

12. Folkehelseinstituttet. Helseskadelige organiske miljøforurensninger i mat (dioksiner, PCB, bromerte og fluorerte forbindelser).

https://www.fhi.no/nettpub/fremmedstoffer-i-mat/ulike-fremmedstoffer-i-mat/helseskadelige-organis ke-miljoforurensninger-i-mat/ Lest 8.12.2020.

13. Ortiz X, Carabellido L, Martí M et al. Elimination of persistent organic pollutants from fish oil with solid adsorbents. Chemosphere 2011; 82: 1301-7. [PubMed][CrossRef]

14. Caspersen IH, Knutsen HK, Brantsæter AL et al. Dietary exposure to dioxins and PCBs in a large cohort of pregnant women: results from the Norwegian Mother and Child Cohort Study (MoBa). Environ Int 2013; 59:398-407. [PubMed][CrossRef] 
Publisert: 18. februar 2021. Tidsskr Nor Legeforen. DOI:10.4045/tidsskr.20.1037

Mottatt 18.12.2020, første revisjon innsendt 1.2.2021, godkjent 3.2.2021.

(C) Tidsskrift for Den norske legeforening 2020. Lastet ned fra tidsskriftet.no 